It is suggested, therefore, that the Egyptian of the time of Menes was starting his year with an observation of the reappearance of Sothis. The threefold division of the year was borrowed from prehistoric customs with some modifications. The three seasons, flood, spring and harvest, each consisted of 120 days. The 'moons' were continued as 'months' for official purpose of 30 days exactly, or three ten-day 'weeks', and the year consisting of twelve months with five days "over and above the year", subject to variation of one day or more owing to inaccurate observation and the occurrence of an extra day each fourth year. This endured during the first two dynasties, yet it is known that throughout the later historical period the year differed from the star and the Nile. When was this "wandering" year first used ? Between 1317 B.c., when the New Year coincided with the appearance of the star, and 2773 B.c., there are several items of evidence that the civil calendar was consistently 'wandering' and at variance with the true seasons by about one day for each four years which had elapsed since 2773 B.c. The conclusion is inescapable that in that year the calendar had been in agreement with that star, and that in that year the observations on which that relation had depended were discontinued. The date is astronomically fixed as the start of the wandering calendar of succeeding centuries.

It is suggested that the change may have taken place in connexion with the period of prosperity which followed on the accession of Djoser, founder of the Third Dynasty, in 2778 B.c. The host of census takers, tax collectors and royal scribes who were engaged in managing the land under a powerful centralized government no doubt found a year whose beginning depended upon the observation of a star highly inconvenient, and preferred to adopt a year with a definite period of 365 days. Owing to the discrepancy between this year and the heliacal rising of Sothis amounting to one day in each successive period of four years, by a century or so later it became necessary to observe two New Year days, "the Opener of the Year" or "the Coming Forth of Osiris" and "The First of the Year", the latter in all likelihood being the New Year inserted into the calendar when it became definitely and obviously separated from Nature. When the ealendar became less and less dependable in foretelling the true season, it was probably the time at which the priests invented the coronation oath which called for the new king to swear "never to intercalate a month or a day, nor to vary a festival, but to preserve the 365 days as they were ordained of old".

On the view here put forward the ancient Egyptian calendar was not an invention on any one day at dawn, when a series of phenomena happened to coincide, but it was a gradually developed method of predicting approximately the almost unpredictable rise of the Nile. For a few centuries before 2773 B.c. it depended upon observation of the reappearance of Sothis, and the resulting self-adjusting year was as true a measure of solar time as was the later Julian year. As man became more cultivated he felt the need of some measure of time-reckoning more definite than Nature itself. In 2773 B.c. he dropped the New Year observations and took up the 365-day year, which actually brought his seasons back into their original places only once again during his whole history.

\title{
THE FUEL RESEARCH BOARD
}

$\mathrm{T}$ HE report of the Fuel Research Board for the year ending March 31, 1939, has recently appeared*, As this date was passed more than one and a half years ago the contents have lost their freshness. They reveal the measure of activity of national research on fuel problems before the outbreak of war and allow the reader to judge of the use made of the results.

The report opens with the work of the coal surveyone of the most important branches of the Board's activity. To realize this it is only necessary to recall the limited and superficial character of the scientific data about British coals during the War of 1914-18. The information accumulated in the meantime has already been turned to good use. It is also noticeable that the survey officers have passed the mere compilation of analytical data and have been able to reach valuable conclusions about the properties and applications of coal and the geology of the coalfields.

The growing importance of coal preparation is shown by the length of the relevant section, which reaches forty pages. Coal users are no longer content with any fuel, and even the householder is unwilling to receive and break under his own roof large lumps

* Department of Scientific and Industrial Research. Report of the Fuel Research Board for the Year ended 31st March 1939, with Report of the Director of Fuel Research. Pp. iv +206. (London: H.M. Stationery Office, 1940.) 38. $6 d$. net. of fuel. Modern housing is not designed to store large stocks of dirty material which necessitates manual preparation before use. Effort is being made to prevent dust by coating lump coal with oils and hygroscopic salt solutions--problems which give rise to interesting physical problems. Although the distribution of fuel in fluid form has obvious advantages, war-time conditions show that there is merit in the possession of household stocks of solid fuel which a dispersed population can enjoy.

Oil synthesis from coal by different routes occupies the largest share of the report. Coal and coal tarsparticularly the latter-form a source of liquid fuel. Hydrogenation of tars and oils was applied first to low-temperature tars and continued with gasworks tars, then coke-oven tars. As the work has proceeded the discovery of more active catalysts has enlarged the scope of the process.

The production of lubricants from coal has proved more difficult than the production of fuels, at any rate by hydrogenation. More promise is shown by synthesis from mixtures of carbon monoxide and hydrogen-the so-called Fischer-Tropsch process. By polymerization, certain fractions have been converted to products similar to natural lubricating oils suitable for internal combustion engines. Although these were not equal to the Air Ministry's standard, the hope is expressed that this will be reached. 
The use of gas producers for propelling readvehicles has been studied at the Fuel Research Station since 1923 and in recent years more intensely. The work reported has been concerned mainly with the choice of suitable fuels and done largely in close association with the officers of the Coal Survey. The number of vehicles propelled by producer gas and seen on the roads is relatively small - possibly because the need for petrol substitutes has not been too pressing. There has, however, been no lack of scientific and industrial effort.

The section on domestic heating is largely concerned with the measurement of smoke emission and the means for its abatement. It was found that design of fire-places conducive to securing admixtures of products of combustion with air and to conserving their high temperature would make a considerable reduction in smoke. Unfortunately, present circumstances do not make the advantages of smoke reduction so evident as they will be when peace returns.

H. J. Hodsman.

\section{FORTHCOMING EVENTS}

\section{Wednesday, January 8}

Royal Society of Medicine (at, $\mathbf{l}$ Wimpole Street, London, W.1.) at 2.30 p.m. Prof. S. Zuckerman : "The Problem of Blast Injuries."

\section{APPOINTMENTS VACANT}

APPLICATIONS are invited for the following appointments on or before the dates mentioned:

PRINCIPAL OF LISBURN TECHNICAL SCHOOL AND ORgaNIZER OF TECHNICAL EDUCATION-The Secretary, Lisburn and Belfast (Rural) Regional Education Committee, Castle Chambers, Lisburn, Co. Regional Education
Antrim (January 15).

Lecturer in Mechanical Engineering-The Principal, Walsal Technical College, Bradford Place, Walsall (January 18).

Assistant Executive EngIneERs in the Punjab Service of Engineers, Class I-The High Commissioner for India, General Department India House, Aldwych, London, W.C.2 (quoting Appointment 1/11/A) (January 24).

PROFESSOR OF ANATOMY-The Secretary and Registrar, University, Bristol (January 30 ).

TEACHER OF Electrical EngINEmRING in the Smethwick Municipal College-The Chief Education Officer, 215 High Street, Smethwick.

Senior LeCTURER IN Mechanical Engineering-The Clerk to the Governors, South-West Essex Technical College and School of Art, Forest Road, Walthamstow, London, E.17.

\section{REPORTS AND OTHER PUBLICATIONS}

\author{
(not included in the monthly Books Supplement)
}

\section{Great Britain and Ireland}

Amgueddfa Genedlaethol Cymru: National Museum of Wales. Mammals and Man : Handbook to a Temporary Exhibition, November 1940 to April 1941. By Colin Matheson. Pp. 22. (Cardiff : National Museum of Wales and Press Board of the University of Wales.) $3 d$.

Proceedings of the Royal Society of Edinburgh, Session 1939-1940. Vol. 60, Part 3, No. 26: Some Confluent Hypergeometric Functions of Two Variables By A. Erdélyi, Pp. 344-361. 1s. 6d. Vol. 60 Part 4, No. 27: The Design and Interpretation of Experiments based on a Four-fold Table; the Statistical Assessment of the Effect of Treatment. By Dr. W. O. Kermack and Dr. A. G. M*Kendrick. Pp.
362-375. 18. 3d. (Edinburgh : Robert Grant and Son, Ltd.; London: $362-375.18 .3 d$. (Edinburgh : Robert Grant and Son, Ltd. ; London :
Williams and Norgate, Ltd.)

Department of Scientific and Industrial Research. Index to the Literature of Food Investigation. Vol. 12, No. 1, June 1940. Compiled by Agnes Elisabeth Glennie, assisted by Gwen Davies and Catherine Robson. Pp. iv +74 . (London: H.M. Stationery Office.) 48. $6 d$. net.

$[512$

Hannah Dairy Research Institute. Annual Report for the Year ending 31st March 1940. Pp. $20+4$ plates. (Kirkhill : Hannah Dairy
Research Institute.)
Town Planning Institute. Town and Country Planning: Conpeusa. tion and Betterment. Report of Committee of the Institute approved by the Couneil of the Institute, 31st May 1940. Pp. 60. (London: Town Planning Institute.)

$[612$

Memoirs of the Cotton Research Station, Trinidad. Series B : Physiology. No. 13: The Effect of Ringing on the Upward Movement of Solutes from the Root; The Effect of Ringing and of Transpiration of Mineral Uptake. By E. Phillis and T. G. Mason. Pp. 16. (London: on Mineral Uptake. By E. Phillis and T. G. Mason. Pp. 16. (London:
Fmpire Cotton Growing Corporation.) 2s. 6d.

University of London : Institute of Archaeology. Geochronological Table No. 2: The Age of Neanderthal Man, with Notes on the Cotte de St. Brelade, Jersey, C.I. By Frederick E. Zeuner. (Occasional Paper 3.) Pp. 20. (London: Institute of Archaeology.) 38. [1012 The Control and Extermination of Wild Rabbits. By A. D. MiddleHerbage Publication Series. Bulletin 30: The Grasslands of the
Argentine and Patagonia. By William Davies. Pp. $48+7$ plates. (Aberystwyth: Imperial Bureau of Pastures and Forage Crops.) (Aberystwyth: Imperial Bureau of Pastures and Forage Crops.)
$2 s .9 d$.

Amgueddfa Genedlaethol Cymru: National Museum of Wales. Thirty-third Annual Report 1939-40 presented by the Council to the Court of Governors on the 25th October 1940 . Pp. $49+2$ plates. (Cardiff: National Muscum of Wales.)

\section{Other Countries}

Siuthern Rhodesia Geological Survey. Short Report No. 32 : Report on the Geology and Mines of the Insiza-Fort Rixon Gold Belt. By on the Geology and Mines of the Insiza- Fort Rixon Gold Belt. By
R. Tyndale-Biscoe. Pp. 23. (Salisbury : Government Printer.) [212 Report of the Aeronautical Research Institute, Tôkyô Imperial University. No. 191: Measurement of the Period of Natural Vibration of an Airscrew Blade. By Jûichi Obata and Yahei Yosida. Pp. 97108. 30 sen. No. 192 : Viscosity Characteristics of Lubricating Oils as related to their Chemical Structure. By Bunnosuke Yamaguchi. Pp. 109-136. 50 sen. No. 193: Dynamical Stability of a Column under Periodic Longitudinal Forces. By Ikuo Utida and Katsutada Sezawa. Pp. 137-184. 80 sen. No 194: On the Subsonic Flow of a Compressible Fluid past an Elliptic Cylinder. By Isao Imai and Takasi Aihara. Pp. 185-212. 45 sen. No. 195: Some Experiments on the Forced Vibration of Varying Period. By Katsutada Sezawa and Wataru
Watanabe. Pp. 213-228. 30 sen. (Tôkyô : Kôgyô Tosho Kabushiki Watanabe. Pp. 213-228. 30 sen. (Tôkyô : Kôgyô Tosho Kabushiki
Kaisha.)

New Zealand: Marine Department. Fisheries Bulletin No, 8: Natural Reproduction of Trout in New Zealand and its Relation to Density of Populations. By Derisley F. Hobbs. Pp. 93. (Wellington: Gensity or Populations. By Derisley F. Hobbs. Pp. 93. (Wellington:
[312 Bulletin of the American Museum of Natural History. Vol. 77, Art. 5: Meryochoerinae, a New Subfamily of Oreodonts. By C. Bertrand Schultz and Charles H. Falkenbach. Pp. 213-306. (New
York: American Museum of Natural History.)

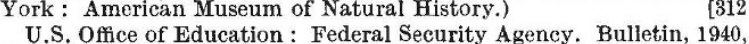
No. 2: Statisties of Public High Schools, 1937-38. (Biennial Survey of Education in the United States, Chapter 5.) Statistical Tables prepared under direction of David T. Blose ; Text prepared by Carl A. Jessen. Pp. vi+192. (Washington, D.C.: Government Printing

Madras Fisheries Department. Administration Report for the Year 1938-39. By Diwan Bahadur Dr. B. Sundara Raj. Po. iii + $76+2$. (Madras: Government Press.) 8 annas. Proceedings of the United States National Museum. No. 3077 : Proceedings of the United States National Museum, No. 3077 .
Further Studies on the Opalinid Ciliate Infusorians and their Hosts. Further Studies on the Opalinid Ciliate Infusorians and their Hosts. By Maynard M. Metcalf. Pp. 465-634. (Washington, D.C. : Govern-
ment Printing Office.)

Anthropological Records. Vol. 2, No. 5: The Social Organization of the Haisla of British Columbia. By Ronald L. Olson. Pp. 165-200. 35 cents ; 28 . net. Vol. 4, No, 1 : Culture Element Distributions, 12: Apache-Pueblo. By E. W. Gifford. Pp. vi +208. 2 dollars; 128. net. (Berkeley, Calif.: University of California Press ; London :
Cambridge University Press.)

New Zealand: Department of Lands and Survey. Annual Report on Public Domains and National Parks of New Zealand. Pp. 10. 6d. Report on Scenery Preservation for the Year ended 31st March 1940. Report on Scenery Preservation for the Year ended 31st March 1940. The Dissection of the Shark Eulamia menisorrah (Hüller and Henle): an Illustrated Guide for the use of First-Year University Students. By G. A. C. Herklots. Pp. 28. (Hong Kong: The University.)
1 dollar; 28 . 1 dollar ; 28.

$[1012$ 1940, No. 1: Educational Directory, 1940. Pp iv $+48+28+86+72$ Know Your School Leaflet No. 55: Know Your State Educationa Program. By W. S. Deffenbaugh. Pp. iv +26 . 5 cents. (Washington. D.C.: Government Printing Office.)

Commonwealth of Australia. Report of the Director of the Commonwealth Solar Observatory to the Advisory Board. Pp. 8. (Canberra. Commonwealth Government Printer.)

$[1012$

Malavan Forest Records. No. 13: Timber Utilization in Malaya By H. E. Desch and A. V. Thomas. Pp. ix $+81+35$ plates. (Kual Sumpur: Forest Department.) 3 dollars ; $78.6 d$.

Canada : Department of Mines and Resources: Mines and Geolog Branch : Geological Survey. Paper 40-13 : Preliminary Map, Wapiabi Creek, Alberta. By B. R. MacKay. 10 cents. Memoir 222: Malartic Area, Quebec. By H. C. Cumming and J. W. Ambrose. (No. 2454 .) Pp. v $+142+7$ plates +4 maps. 50 cents. (Ottawa: King's Ministry of Agriculture: Technical and Scientific Serviee. Bulletin
No. 150: Hot Air Treating Machines used in the Ginneries for the No. 150: Hot Air Treating Machines used in the Ginneries for the Destruction of Pink Boll Worm in the Cotton Seed, By Monammal. Pp. $20+40$ plates. P.T. 5. Bulletin No. 219: Fariety-Tests on some Introduced Sugar Cane Varieties. By Gadalla Aboul Ela. Pp. 14. P.T. 2. (Cairo: Government Press.) $\{1912$ 